Jacek Pasieczny

Dr. habil., Professor, University of Warsaw, Warsaw, Poland

\title{
REVIEW OF THE MONOGRAPH "STRATEGIC MANAGEMENT OF THE DEVELOPMENT OF RESEARCH UNIVERSITIES” BY MAKSYM SITNICKI ${ }^{1}$
}

JEL classification: $\mathrm{Y} 30$.

\section{Я. Пасєчни}

доктор габілітований, професор, керівник департаменту інновацій і підприємництва Варшавського університету, Варшава, Польща

\section{ОГАЯА МОНОГРАФІЇ М. В. СИТНИЦЬКОГО “СТРАТЕГІЧНЕ УПРАВАІННЯ РОЗВИТКОМ АОСАІАНИЦЬКИХ УНІВЕРСИТЕТІВ”}

\section{Я. Пасечны}

доктор хабилитированный, профессор, руководитель департамента инноваций и предпринимательства Варшавского университета, Варшава, Польша

\section{ОБЗОР МОНОГРАФИИ М. В. СИТНИЦКОГО

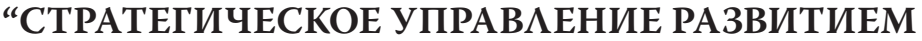 ИССАЕАОВАТЕАЬСКИХ УНИВЕРСИТЕТОВ”}

For the European Union, at present, an important task is increasing competitiveness of research universities in the context of intensifying their innovation activities, which will make possible to attain leading positions in global rankings of world-class universities. The search for effective means to strengthen their competitive positions is portrayed in studies of successful international experience in strategic management of the development as regards the world leading research universities. Current academic activity of business schools in leading research universities and intensification of the processes related to implementation of digital technologies allow developing the entrepreneurial type of thinking of students and scientific and pedagogical workers, attracting the best intellectual potential and providing universities with financial autonomy. Therefore, the reviewed monograph ${ }^{2}$ is relevant and timely for the investigations into global challenges to the educational and research fields.

The first part of the monograph deals with theoretical foundations of the strategic management in the development of research universities. The important findings and conclusions include:

- a historical retrospective of the development of the research university phenomenon and the renewal of its mission in accordance with modern demands

\footnotetext{
${ }^{1}$ Maksym Sitnicki-Ph. D. (Economics), Associate Professor at the Department of Management of Innovative and Investment Activities of the Faculty of Economics Taras Shevchenko National University of Kyiv.

${ }^{2}$ Sitnicki, M. (2018). Strategic Management of the Development of Research Universities. Kyiv: Lira-K [in Ukrainian].

๑) Jacek Pasieczny, 2019
} 
of the society development is rethought. This builds up a scientific understanding of modern approaches to the strategic management of the development of research universities under dynamic changes in the economy caused by global imperatives of scientific and technological progress;

- the proposed model for the strategic management of the development of research universities. The model's paradigm is based on the systematization of the essential components of development to ensure the effective goal-setting and implementation of strategic goals and missions of institutions of this type. The author has identified six original stages of the process of strategic management of the development of the research university that allowed qualitatively characterize the complete closed cycle from the beginning of the development process and to the stage of its completion. The highest efficiency from the strategic management of the development of the research university is achieved only under prioritizing development of its areas and potentials;

- the effectiveness of the university ranking methodologies is compared with regard to their applicability as a strategic and tool in managing development of educational and research institutions.

The second part offers an advanced approach to treating global practices of strategic management of the development of world-class universities. The part is remarkable with its sound reasoning about pragmatic applicability of the made observations and arrives to some important conclusions:

- the results of a comprehensive analysis of the ranking indicators of worldclass research universities. This approach allows analyzing strategies of the twenty five world best research universities and identify prevailing trends in their development;

- special attention should be paid to the strategic recommendations elaborated in this research to enhance competitiveness of the European Union research universities at the global level.

In the third part, the author discloses an innovative system for assessing development of the research universities. The novel findings contribute to the existing studies in the educational domain:

- essential features of the university ranking system in Poland are distinguished and systematized. The Polish ranking system is considered as the indispensable tool for strategic management of the development of research universities;

- basic university ranking systems applicable throughout the world to manage activities of the research universities are analyzed and compared. A system of relevant criteria is proposed for the implementation of strategic analysis and evaluation of the activities of research universities, which allows objectifying the results of the assessment and minimizing the level of the subjective component of the obtained consolidated results.

The fourth part of the monograph shows the best practices of the business schools in the context of the development of research universities. In particular, the role of business schools is assessed as regards strengthening financial autonomy of the research universities and ensuring promotion of the managerial 
innovations and their popularizing among students, teachers, scientists and practitioners.

The fifth part exposes specific aspects of the strategic development as regards scientific libraries in the research universities. The author reached some sound and valid conclusions as regards:

- some priorities and strategic development ideas for scientific libraries in the research universities of the European Union. The proposals are outlined on the basis of a diagnosis of global trends in the development of science and education;

- a franchising model is developed for commercializing services of scientific libraries of the research universities. This managerial solution is expected to strengthen financial autonomy of the institutions and activate their development.

In the sixth part, the author explores strategic tools to implement the concept of managing development of the research universities in Poland and Ukraine by suggesting:

- a conceptual model of entrepreneurship development in the research universities, which allows with an innovative type of thinking to raise effectiveness of the institution's intellectual potential and expertise;

- the author's vision of the digital university concept is offered, which allows providing educational and research services at the global level using effective tools for generating and translating knowledge;

- practical proposals for establishing on innovative principles the scientific service centers in the research universities.

The conclusions summarize the essence of the obtained results and underline the complex nature of the conducted research, its theoretical practical importance.

The obtained results were reported in full in over twenty articles in various journals of the European Union and Eastern Europe. The results were discussed at numerous international research conferences. The author published his articles and conference theses in English, Polish and Ukrainian. The publications are indexed in international scientometric databases: Scopus, Web of Science and others.

Main conclusion. The reviewed monograph Strategic Management of the Development of Research Universities is a comprehensive scientific research with its elements of scientific novelty.

The book highlights both global and Polish experience in strategic management of the research universities and strengthens international cooperation between leading research universities in Poland and Ukraine. The publication is useful and recommended for university leaders, students, professionals and researchers involved in strategic management. 